\title{
Characterisation of the $\beta$ adrenergic response cascade in fetal guinea pig lung
}

\author{
Martha E Lyon, Charles A Lefebvre, Deborah J Davis
}

\begin{abstract}
Background - Suitable models for the study of lung development are needed. The suitability of the guinea pig for studying the role of the $\beta$ adrenergic response cascade in fetal lung development has been evaluated.

Methods - Radioligand binding assays with iodine-125 labelled iodopindolol were performed to identify and characterise the $\beta$ adrenergic receptors. To demonstrate that these receptors were functional, isoprenaline and forskolin stimulated generation of cyclic AMP (cAMP) in the lung tissue was quantitated by radioimmunoassay.

Results - The concentration of $\beta$ receptors increased with gestational age from $23 \mathrm{fmol} / \mathrm{mg}$ at 35 days to $140 \mathrm{fmol} / \mathrm{mg}$ at 64 days. Competition binding studies were consistent with a predominance of $\beta_{2}$ receptors. The ability of isoprenaline to stimulate cAMP generation was greater during the saccular phase than during the canalicular phase of lung development. Incorporation of tritium labelled choline into phosphatidylcholine increased significantly between the canalicular and saccular phases.

Conclusions - The $\beta$ adrenergic response cascade in fetal guinea pig lung exhibits similar characteristics to those previously described in fetal human lung and is therefore a good model in which to study the effects of $\beta$ agonists on fetal lung development.
\end{abstract}

(Thorax 1994;49:664-669)

Inadequate lung development in many premature babies leads to respiratory distress syndrome, a disorder characterised by surfactant deficiency, excess alveolar and interstitial lung water, and morphological immaturity of the lung. ${ }^{1}$ There is clinical and experimental evidence which indicates that surfactant synthesis and secretion are mediated, in part, by $\beta$ adrenergic responses. ${ }^{23}$ Further studies may identify the mechanisms by which the $\beta$ adrenergic response cascade mediates surfactant synthesis and secretion and, perhaps, uptake and utilisation of exogenous surfactant, but appropriate experimental models are needed. Owing to ethical considerations fetal human lung of appropriate gestational ages is not always readily available, necessitating the use of another animal model. Although rabbits and rats are commonly used in studies of lung development, we felt that fetal guinea pigs would be a more suitable animal model for several reasons. Firstly, the guinea pig has a longer gestation (67-69 days) than rabbits and rats and is also relatively mature at the time of delivery. ${ }^{4}$ Secondly, the proportion of time spent in the different stages of morphological maturation of the lung and the timing of these stages in relation to delivery in the guinea pig ${ }^{5}$ are more similar to those in the human than those in the other small mammals. For example, the saccular stage of lung development begins by 50 days $(75 \%$ of gestation) in the guinea pig ${ }^{5}$ and by 28 weeks ( $70 \%$ of gestation) in the human fetus, ${ }^{6}$ whereas the rabbit and rat only reach the saccular stage by $90-95 \%$ of gestation. ${ }^{7}$ In addition, in both the guinea pig $^{8}$ and the human ${ }^{6}$ alveolarisation of the lung is well established before term, and surfactant synthesis ${ }^{9}$ and induction of antioxidant enzymes ${ }^{10}$ occur relatively late in gestation in both. The purpose of this study was to characterise $\beta$ adrenergic responses in fetal guinea pig lung in order to assess the appropriateness of this model to study the involvement of the $\beta$ adrenergic response cascade in lung development.

\section{Methods}

ANIMALS

All animal experiments were approved by the Animal Care Committee of the University of Ottawa and conformed with the guidelines outlined by the Canadian Council for Animal Care. ${ }^{11}$

Following a one week acclimatisation timed pregnant 3-4 month old Hartley guinea pigs (Charles River Breeders, Quebec, Canada) were sacrificed by intracardiac injection of sodium pentobarbitone. The fetuses were delivered by hysterotomy and were immediately euthanised with intraperitoneal injection of sodium pentobarbitone if they showed any signs of life. The fetuses were weighed and their gestational age was assigned using the table of Draper ${ }^{12}$ which reports average fetal weight as a function of gestational age. The fetal lungs were excised under sterile conditions and placed in $50 \mathrm{mmol} / 1 \mathrm{Tris} / 1 \mathrm{mmol} / \mathrm{l}$ EDTA.

\section{MEMBRANE PREPARATION}

Because $\beta$ adrenergic receptors are found in cell membranes, membrane particulates were prepared from the excised lungs; the lungs were minced in $50 \mathrm{mmol} / 1$ Tris $/ 1 \mathrm{mmol} / 1$ EDTA and filtered through cheesecloth before centrifugation at $1200 \mathrm{~g}$ for 15 minutes. The supernatant was then centrifuged at $29000 \mathrm{~g}$ 
for 15 minutes and the resulting pellet was washed three times in $50 \mathrm{mmol} / 1 \mathrm{Tris} / 4 \mathrm{mmol} / 1$ $\mathrm{MgCl}_{2}$ as previously described. ${ }^{13}$ The protein concentrations of the particulates were determined according to the method of Bradford ${ }^{14}$ with bovine serum albumin as the standard. The membrane particulates were frozen in a dry ice/ethanol bath and stored at $-70^{\circ} \mathrm{C}$ until assayed.

\section{RADIOLIGAND BINDING ASSAYS}

There were no previous data on $\beta$ adrenergic receptors in fetal guinea pig lung so the experimental conditions were first validated by a series of studies designed to assess the optimal incubation time, protein concentration, conditions of the incubation and wash buffer, and subcellular fraction to be assayed. For saturation analysis of radioligand binding experiments the incubation time must be long enough to ensure that a steady state is reached, but not so long that any decrease in binding occurs. This time required to reach steady state between the radioligand and the $\beta$ receptors was determined by incubating $200 \mathrm{pmol} / \mathrm{l}$ iodine-125 labelled iodopindolol with membrane particulates $(20 \mu \mathrm{g}$ protein $)$ in a buffer of $50 \mathrm{mmol} / 1 \mathrm{Tris} / 4 \mathrm{mmol} / 1 \mathrm{MgCl}_{2}(\mathrm{pH} 7 \cdot 4$ ), $1 \mathrm{mmol} / 1$ ascorbic acid, and either $0.1 \mathrm{mmol} / \mathrm{l}$ $\mathrm{HCl}$ for total binding or $0.1 \mathrm{mmol} / 1$ isoprenaline in $0.1 \mathrm{mmol} / 1 \mathrm{HCl}$ for non-specific binding, at $30^{\circ} \mathrm{C}$ for $1-90$ minutes. At the prescribed times the incubation was stopped by the addition of $5 \mathrm{ml}$ ice cold $50 \mathrm{mmol} / 1$ Tris/ $4 \mathrm{mmol} / \mathrm{l} \mathrm{MgCl}$; bound and free ligand were separated by filtration over Whatman $\mathrm{GF} / \mathrm{C}$ filters. The filters were washed three times and the radioactivity on the filters was counted to determine the specific radioligand binding over time. Apparent steady state between the $\beta$ receptors and ${ }^{125} \mathrm{I}$-iodopindolol was reached by 30 minutes as shown by constant specific binding beyond this time. All subsequent experiments used an incubation time of 45 minutes to ensure that steady state conditions existed.

The optimal protein concentration to perform saturation analysis studies was determined by incubating ${ }^{125} \mathrm{I}$-iodopindolol $(200 \mathrm{~mol} / \mathrm{l})$ with membrane particulates $(0$ $60 \mu \mathrm{g}$ protein) as described above. From these experiments it was determined that to ensure optimal detection of the $\beta$ receptors and less than $20 \%$ non-specific binding a minimum of $20 \mu \mathrm{g}$ membrane protein was required.

Using similar methods specific radioligand binding was determined at incubation temperatures of $4^{\circ} \mathrm{C}, 22^{\circ} \mathrm{C}, 30^{\circ} \mathrm{C}$, and $37^{\circ} \mathrm{C}$; maximal specific radioligand binding was determined to be at $30^{\circ} \mathrm{C}$ so this temperature was used in subsequent experiments. Similarly, a total of three washes with ice cold buffer, rather than room temperature or $37^{\circ} \mathrm{C}$ buffer, was found to be optimal and was used in subsequent experiments.

To determine which subcellular fraction of fetal guinea pig lung contained the largest concentration of $\beta$ receptors, the amount of total, non-specific and specific binding of ${ }^{125} \mathrm{I}$ iodopindolol to the $\beta$ receptors was monitored as described above in the following fractions obtained from differential centrifugation: (1) $1200 \mathrm{~g}$ pellet $\left(15\right.$ minutes at $\left.4^{\circ} \mathrm{C}\right)$; (2) $29000 \mathrm{~g}$ pellet ( 15 minutes at $\left.4^{\circ} \mathrm{C}\right)$; (3) $100000 \mathrm{~g}$ supernatant $\left(60\right.$ minutes at $\left.4^{\circ} \mathrm{C}\right)$. The largest $\beta$ receptor concentration was located in the $29000 \mathrm{~g}$ pellet so this protein was used for the radioligand binding analyses.

Having thus optimised the assay conditions, saturation analysis experiments were performed to determine the concentration of $\beta$ adrenergic receptors. In these assays duplicate samples of each membrane particulate $(20 \mu \mathrm{g}$ protein) were incubated at $30^{\circ} \mathrm{C}$ for 45 minutes in $0.125 \mathrm{ml}$ buffer containing ${ }^{125} \mathrm{I}$-iodopindolol $(0-500 \mathrm{pmol} / \mathrm{l})$ as described above.

The dissociation constant $\left(\mathrm{K}_{\mathrm{d}}\right)$, which describes the affinity of a ligand for its receptor, was determined from the initial saturation analysis experiments and validated kinetically. ${ }^{15}$ For these kinetic experiments, $\mathrm{k}_{\mathrm{off}}$ was determined by incubating ${ }^{125} \mathrm{I}$-iodopindolol $(500 \mathrm{pmol} / \mathrm{l})$ with membrane particulate $(20 \mu \mathrm{g}$ protein) in $50 \mathrm{mmol} / 1 \mathrm{Tris} / 4 \mathrm{mmol} / 1 \mathrm{MgCl}_{2}$ at pH 7.4 for 30 minutes at $30^{\circ} \mathrm{C}$. At 30 minutes the assay volume was increased 100 fold with $50 \mathrm{mmol} / 1 \mathrm{Tris} / 4 \mathrm{mmol} / 1 \mathrm{MgCl}_{2}$ at $\mathrm{pH} 7.4$ and the incubation continued for an additional 60 minutes. Specific radioligand binding was monitored as a function of time before and after the dilution of the reaction mixture using the radioligand binding assay already described. $K_{o n}$ was calculated as outlined by Roberts. ${ }^{15}$

Since $\beta$ receptors exhibit a higher affinity for the $S$ isomer of a ligand than the $R$ isomer, fetal guinea pig lung preparations were examined for stereoselectivity. Membrane particulates $(20 \mu \mathrm{g}$ protein) were incubated as described above with ${ }^{125}$ I-iodopindolol $(200 \mathrm{pmol} / \mathrm{l})$ and either $\mathrm{S}$ or $\mathrm{R}$ propranolol in decreasing concentrations ( $1 \mathrm{nmol} / 1$ to $10 \mu \mathrm{mol} / \mathrm{l})$. The specific binding of ${ }^{125} \mathrm{I}$-iodopindolol to the $\beta$ receptors was monitored by radioligand binding assay described above.

Beta receptor subtype can be determined by agonist competition assays or by competition assays with specific $\beta_{1}$ or $\beta_{2}$ antagonists. For these assays membrane particulates $(20 \mu \mathrm{g}$ protein) were incubated with ${ }^{125} \mathrm{I}$-iodopindolol $(200 \mathrm{pmol} / \mathrm{l})$ in the presence or absence of $\beta$ agonists (isoprenaline, adrenaline, or noradrenaline), or a selective $\beta_{1}$ antagonist (atenolol, $1 \mathrm{pmol} / 1-10 \mu \mathrm{mol} / \mathrm{l}$ ), or a specific $\beta_{2}$ antagonist (ICI $118551,1 \mathrm{pmol} / \mathrm{l}-10 \mu \mathrm{mol} / \mathrm{l}$, a gift from Imperial Chemical Industries) for $\mathbf{4 5}$ minutes at $30^{\circ} \mathrm{C}$. The radioligand binding was monitored with the assay described above.

\section{CAMP GENERATION}

To be important in fetal lung development, any $\beta$ receptors that are identified by radioligand binding assays must be functional. To assess this we studied the ability of isoprenaline $(0-50 \mu \mathrm{mol} / \mathrm{l})$ and forskolin $(0-500 \mu \mathrm{mol} / \mathrm{l})$ to stimulate cAMP generation in fetal guinea pig lung of various gestational ages. Approximately $25 \mathrm{mg}$ of lung tissue were incubated in a $0.25 \mathrm{ml}$ volume of $5 \mathrm{mmol} / 1$ Tris and $0.9 \%$ 
sodium chloride ( $\mathrm{pH} \mathrm{7 \cdot 4}$ ), $1 \mathrm{mmol} / 1$ 3-isobutyl1-methylxanthine (a non-specific phosphodiesterase inhibitor), and $0.1 \mathrm{mmol} / 1$ ascorbic acid, with or without isoprenaline or forskolin, at $37^{\circ} \mathrm{C}$ for 10 minutes. The reaction was stopped by adding $0.25 \mathrm{ml}$ of $10 \%$ trichloroacetic acid. The sample was then homogenised and centrifuged. An ether extraction (5 volumes ether: 1 volume sample) was performed three times on the supernatant of each sample. The sample was evaporated to dryness under a stream of air in a $70^{\circ} \mathrm{C}$ dry bath. This cAMP extract was reconstituted in $0.5 \mathrm{ml}$ of $50 \mathrm{mmol} / 1$ sodium acetate ( $\mathrm{pH} 4)$. Cyclic AMP was then determined by a commercially available radioimmunoassay kit (NEN-Dupont). Under our assay conditions the recovery of cAMP $(50,25,10,5,1 \mathrm{pmol})$ was found to be consistently greater than $80 \%$. The variability in recovering $10 \mathrm{pmol} \mathrm{cAMP} / \mathrm{mg}$ wet weight of lung tissue was $10 \%$. The detection limit of this assay was $1 \mathrm{pmol} \mathrm{cAMP} / \mathrm{mg}$ wet weight and there was a $9 \%$ variability in recovering this amount of cAMP.

\section{CHOLINE INCORPORATION}

Finally we wanted to begin to correlate changes in the $\beta$ receptors with evidence of other events in the lung that are felt to be mediated, at least in part, through the $\beta$ adrenergic response cascade. As a potential measure of surfactant synthesis, therefore, incorporation of tritium-labelled choline into phosphatidylcholine was measured. ${ }^{16}$ Fresh tissue was chopped into $1 \mathrm{~mm}$ cubes and incubated on a rocking platform at $37^{\circ} \mathrm{C}$ in Waymouth MB752/1 culture medium (Sigma) with $5 \mu \mathrm{Ci} / \mathrm{ml}$ of ${ }^{3} \mathrm{H}$-choline chloride in an atmosphere of $5 \% \mathrm{CO}_{2} / 95 \%$ air. After four hours the tissue was washed in $0.9 \% \mathrm{NaCl}$ and homogenised using a Teflon homogeniser. The phospholipids were extracted from the homogenate in a 1:1 chloroform:methanol solution as described by Folch et $a l^{17}$ and separated by thin layer chromatography (TLC) on silica coated TLC plates. ${ }^{18}$ The TLC plates were stained in a solution of cupric acetate in sulphuric acid/ethanol and dried for 30 minutes at $125^{\circ} \mathrm{C} .{ }^{18}$ The plates were scraped and the relative amount of radioactivity in the phosphatidylcholine band was determined by liquid scintillation counting.

\section{DATA ANALYSIS}

The saturation analysis data were analysed by the equilibrium binding data analysis (EBDA) program (Elsevier Biosoft) on an IBM compatible desk top computer. Competition data were analysed by the GraphPad InPlot program which provides the best fit final estimates of $\beta$ adrenergic receptor concentration $\left(\beta_{\max }\right)$ and dissociation constant $\left(K_{d}\right)$ from a least squares analysis of different site models. Results for receptor concentrations in the different subcellular fractions, the cAMP stimulation, and choline incorporation data were analysed by an analysis of variance followed by Scheffe's post hoc test. ${ }^{19}$ The data for total $\beta$ receptor concentrations and $K_{d}$ at different gestational ages were analysed using a simple linear regression. Statistical significance was defined as $\mathrm{p}<0.05$. Data throughout are presented as mean (SE).

\section{Results}

Saturation analyses at all gestational ages tested (40-64 days) were linear, indicating a single class of saturable, high affinity binding sites (fig 1); unfortunately there was insufficient tissue from lungs of fetuses $<40$ days of gestation to do full saturation analyses even when whole litters were pooled. In two fetuses (59 days and 60 days) the dissociation constants $\left(K_{d}\right)$ determined from saturation analysis were confirmed kinetically and were very similar - for example, at 60 days $\mathrm{K}_{\mathrm{d}}=37.9 \mathrm{pmol} / 1$ from saturation analysis and kinetically $\mathrm{k}_{\mathrm{on}}=1.33 \times 10^{-9} / \mathrm{mol} / \mathrm{l} / \mathrm{min}$, $\mathrm{k}_{\text {off }}-0.042 / \mathrm{min}$, therefore $\mathrm{k}_{\text {off }} / \mathrm{k}_{\text {on }}=31.6 \mathrm{pmol} / 1$ $=K_{d}$; younger fetuses never had sufficient tissue to perform both sets of experiments simultaneously so we could not validate other saturation analyses kinetically.

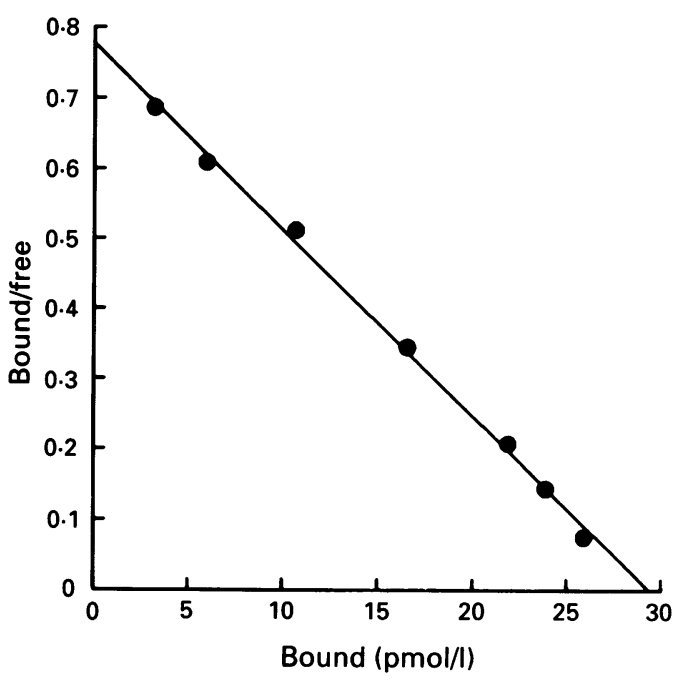

Figure 1 A typical Scatchard plot of ${ }^{125}$ I-iodopindolol specific binding to the $\beta$ adrenergic receptors in a 60 day gestation fetal guinea pig lung from saturation analysis experiments.

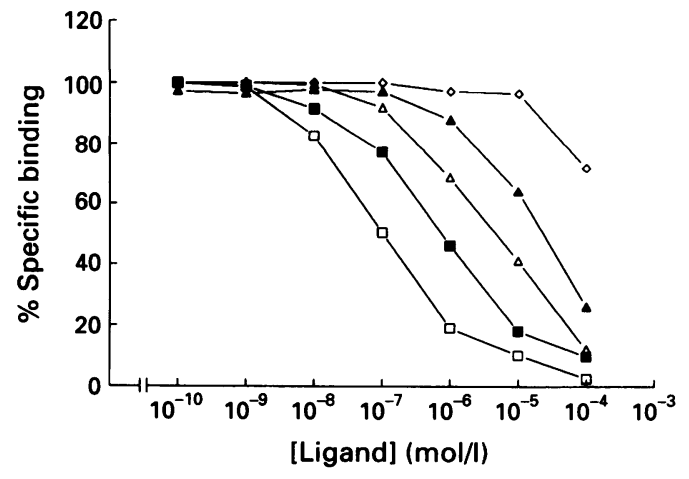

Figure 2 Binding curves for ${ }^{125}$ I-iodopindolol (200 pmol/l) competing with various adrenergic receptor ligands in the presence of different concentrations of isoprenaline ( $\square)$, adrenaline ( $\square)$, noradrenaline $(\triangle)$, atenolol $(\mathbf{\Lambda})$, and phentolamine $(\diamond)$. 

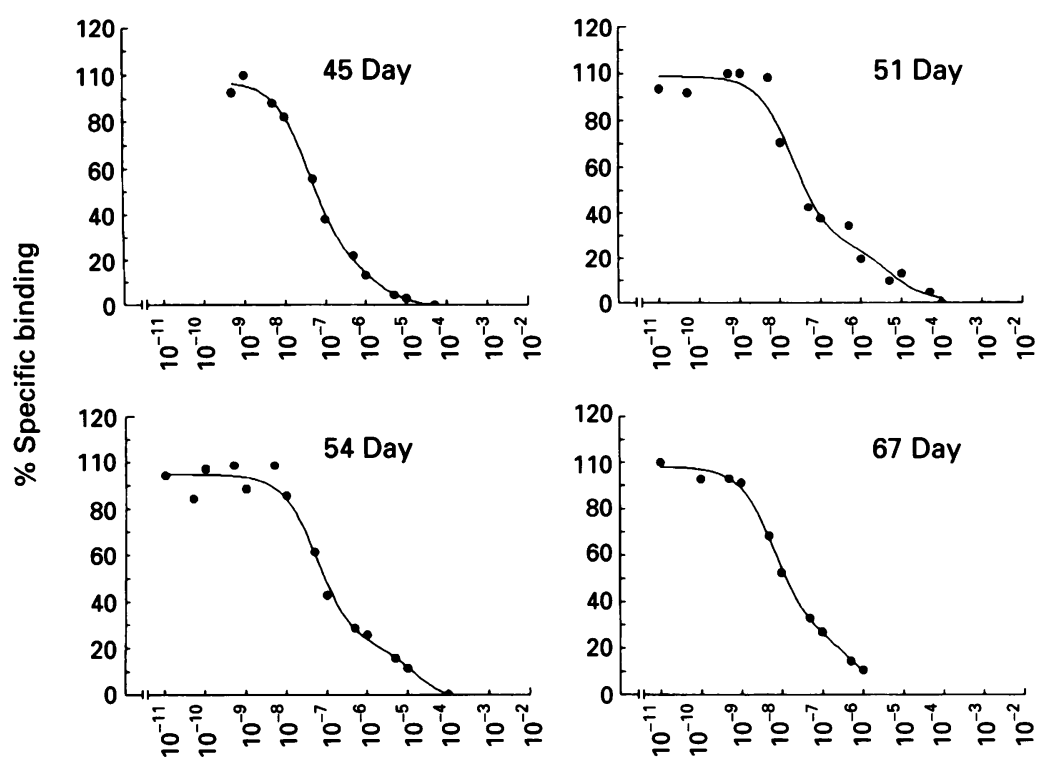

[ICl 118551$](\mathrm{mol} / \mathrm{l})$

Figure 3 Representative binding curves for ${ }^{125}$ I-iodopindolol (200 pmol/l) competing with ICI 118551 in membranes from guinea pig lung of different gestational ages. Analysis of these competition curves and seven others not shown showed that the percentages of $\beta_{1}$ and $\beta_{2}$ receptors and the inhibition constants $\left(K_{i}\right)$ at the gestational ages tested were not different.

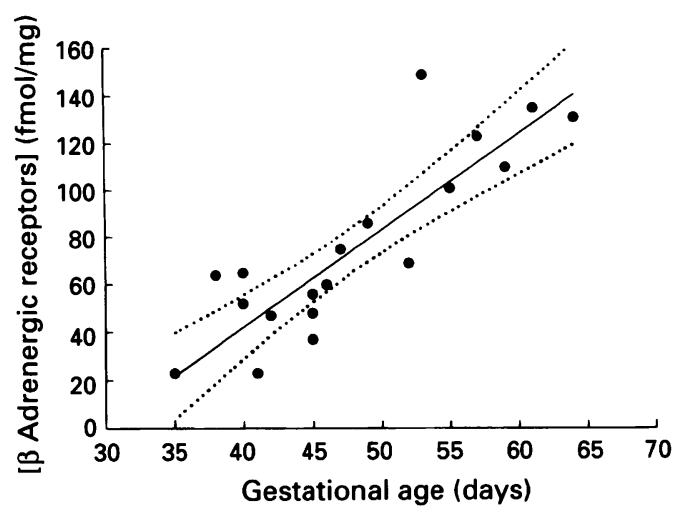

Figure 4 Changes in the concentration of $\beta$ adrenergic receptors with gestational age in fetal guinea pig lung $(r=0.862, p<0.0001)$. The concentration of $\beta$ adrenergic receptors was determined by full saturation analysis in 13 specimens and by one point analysis using

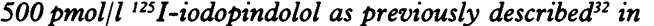
six specimens because of insufficient tissue to perform full analysis.

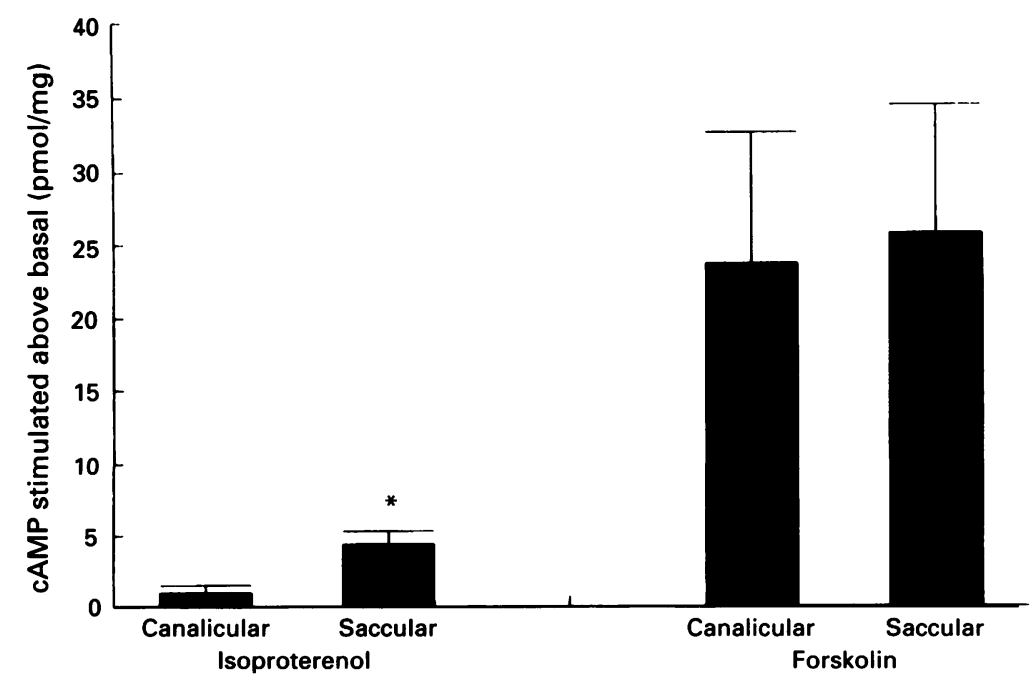

Figure 5 Mean (SE) cAMP generation in fetal guinea pig lung during the canalicular and saccular phases of lung development $(n=4)$. The amount of $c A M P$ stimulated above basal levels is indicated on the vertical axis. ${ }^{*} p<0.05$ between $c A M P$ generated during the canalicular and saccular phases.
The $\beta$ receptors we identified demonstrated stereoselectivity for the $R$ and $S$ isomers of propranolol; the pharmacologically active $S$ isomer exhibited a higher affinity for the $\beta$ receptors $\left(\mathrm{EC}_{50}=2.5 \times 10^{-8} \mathrm{~mol} / \mathrm{l}\right)$ than the $\mathrm{R}$ isomer $\left(\mathrm{EC}_{50}=2 \times 10^{-6} \mathrm{~mol} / \mathrm{l}\right)$.

As an index of $\beta$ receptor subtypes, competition assays were performed to monitor the ability of various adrenergic agents to compete with ${ }^{125}$ I-iodopindolol. The order of potency of the agonist affinities (isoprenaline $>$ adrenaline $>$ noradrenaline) was indicative of a predominance of $\beta_{2}$ receptors (fig 2). Confirmation of this observation by competition assays with ICI 118551 , a specific $\beta_{2}$ antagonist, showed that $\beta_{2}$ receptors predominated throughout the time points of gestation studied (41-67 days). Approximately $65 \%$ (95\% CI $57 \%$ to $74 \%$ ) of the receptors were $\beta_{2}$ and $35 \%(95 \%$ CI $26 \%$ to $43 \%)$ were $\beta_{1}$ $(n=11)$; this did not change with gestation (fig 3). The inhibition constant $\left(\mathrm{K}_{\mathrm{i}}\right)$ for the high and low affinity sites determined from displacement of ${ }^{125} \mathrm{I}$-iodopindolol binding by ICI 118551 were $7 \mathrm{nmol} / 1$ (95\% CI 1.08 to $23.56 \mathrm{nmol} / \mathrm{l})$ and $1.04 \mu \mathrm{mol} / \mathrm{l}(95 \% \mathrm{CI} 0.33$ to $3.25 \mu \mathrm{mol} / \mathrm{l})$. The $\mathrm{K}_{\mathrm{i}}$ for displacement of iodopindolol binding by atenolol was $17 \mu \mathrm{mol} / \mathrm{l}$ (95\% CI 6.9 to $42.2 \mu \mathrm{mol} / \mathrm{l})$. These values are consistent with those previously described for human fetal lung. ${ }^{13}$

The concentration of total $\beta$ receptors progressively increased from $23 \mathrm{fmol} / \mathrm{mg}$ at 35 days of gestation to $140 \mathrm{fmol} / \mathrm{mg}$ at 64 days gestation (fig 4). The mean (SE) $\mathrm{K}_{\mathrm{d}}$ did not change with gestational age (110 (9.7) pmol/l, range $\quad 37-178 \mathrm{pmol} / \mathrm{l}, \quad \mathrm{n}=13) \quad(r=0.004$, $\mathrm{p}>0.05)$.

To determine whether these receptors were functional, the ability of $\beta$ agonists to stimulate cAMP was examined. In the saccular phase of lung development ( $>50$ days) isoprenaline stimulated $50 \%$ more cAMP than was present in the basal state (fig 5). There was no significant stimulation of cAMP by isoprenaline in the canalicular phase of lung development (40-49 days) (fig 5). No gestational differences were observed with forskolin stimulated cAMP generation (fig 5). Mean (SE) basal levels of cAMP were $8 \cdot 1(0 \cdot 86) \mathrm{pmol} / \mathrm{mg}$ wet weight of tissue and did not change with gestation.

Finally, incorporation of ${ }^{3} \mathrm{H}$-choline into phosphatidylcholine, a potential measure of surfactant synthesis, was greater in the saccular (58.65 $(6.3) \mathrm{cpm} / \mathrm{mg}$ tissue) than in the canalicular (34.6 (2) $\mathrm{cpm} / \mathrm{mg}$ tissue) phase of lung development $(\mathrm{p}<0.005)$.

\section{Discussion}

Neonatal respiratory distress syndrome is a disease that is characterised by anatomical immaturity of the lung, excess lung water, and surfactant deficiency. The resorption of lung water and synthesis and secretion of surfactant phospholipids and surfactant associated proteins are mediated, in part, by $\beta$ adrenergic responses. ${ }^{2320-24}$ Beta adrenergic receptors have been identified in fetal rabbit and rat lung, ${ }^{23}$ as well as in human fetal lung from 
early in the second trimester of gestation. ${ }^{1325}$ Human fetal lung is the ideal model for studying the role of the $\beta$ adrenergic response cascade in lung development; however, ethical considerations limit the availability of gestation-appropriate samples. Fetal rabbit lung is one of the most commonly used models in which to study $\beta$ adrenergic responses in fetal lung development, despite the predominance of $\beta_{1}$ receptors $^{26}$ in contrast to the predominance of $\beta_{2}$ receptors in human fetal lung. ${ }^{13}$ Fetal rat lung has also been used. It has similar proportions of $\beta$ receptor subtypes ${ }^{27}$ to those found in humans, but the proportion of time spent in each of the various stages of lung development in the fetal rat is quite different from that in human fetal lung. ${ }^{7}$ The $\beta$ adrenergic response cascade in fetal guinea pig lung has not been previously reported. However, the relative proportion of $\beta_{1}$ to $\beta_{2}$ receptors in the adult guinea pig is similar to that in the human lung ${ }^{2829}$ and the concentration of $\beta$ receptors, especially in the alveolar and bronchial wall epithelium, increases from the newborn to the adult. ${ }^{30}$

Our studies show that characteristic $\beta$ adrenergic receptors are present in fetal guinea pig lung. Binding of ${ }^{125} \mathrm{I}$-iodopindolol to $\beta$ receptors in fetal guinea pig lung is saturable and of high affinity; these findings are similar to those in fetal human lung. ${ }^{13}$ The concentration of $\beta$ adrenergic receptors increases with gestational age in fetal guinea pig lung in a similar way to fetal rabbit, ${ }^{326}$ fetal rat, ${ }^{327}$ and fetal human lung. ${ }^{13}$ The order of potency of agonist affinities and competition studies with a specific $\beta_{2}$ antagonist indicates a predominance of $\beta_{2}$ receptors similar to that in fetal human lung ${ }^{13}$ and fetal rat lung, ${ }^{27}$ but unlike fetal rabbit lung. ${ }^{26}$

To determine whether the $\beta$ adrenergic receptors were functional we examined the ability of $\beta$ agonists to stimulate cAMP and found that there was significant isoprenaline stimulated CAMP generation in the saccular phase of lung development. In contrast, there was no difference detected in the ability of forskolin - a direct activator of adenylate cyclase - to stimulate cAMP generation in the saccular phase compared with the canalicular phase of lung development. Since $\beta$ receptors are linked to the catalytic moiety of adenylate cyclase via guanine nucleotide regulatory proteins ( $G$ proteins), it is possible that there is a gestational change in the amount or function of these $\mathrm{G}$ proteins.

The synthesis and secretion of both surfactant phospholipids ${ }^{20-22}$ and surfactant associated protein $\mathrm{s}^{2324}$ are controlled in part by $\beta$ adrenergic mechanisms. In our studies we found gestational changes in the ability of isoprenaline to stimulate cAMP in fetal guinea pig lung. Interestingly, the gestational age pattern for isoprenaline stimulation of cAMP was associated with a similar pattern for choline incorporation into phosphatidylcholine, which could indicate increased synthesis of either surfactant phospholipids or membrane phospholipids. It is not known whether similar associations exist in fetal human lung between the canalicular and saccular phases of lung development, nor whether this is important in the preparation for extrauterine life. In fetal rabbits administration of an irreversible $\beta$ adrenergic antagonist (bromacetylalprenololmethane) during the saccular phase of lung development decreases both the number of receptor binding sites and the phospholipid content of lung lavage fluid..$^{31} \mathrm{We}$ have not yet performed experiments to determine if blocking the $\beta$ receptors in fetal guinea pig lung has any effects on surfactant production.

In conclusion, the $\beta$ adrenergic response cascade in fetal guinea pig lung exhibits similar characteristics to those previously described in fetal human lung. This, combined with several other aspects of fetal guinea pig development, indicate that fetal guinea pig lung is a better small animal model to study the role of the $\beta$ adrenergic response cascade in lung development and adaptation to extrauterine life. Even in this time of successful surfactant therapy for respiratory distress syndrome there is still much to learn about the mechanisms of surfactant synthesis, release, and recycling in the newborn. Current evidence points to a role for $\beta$ adrenergic responses in these functions; an appropriate animal model will help us to understand how better to use these responses in the prevention and treatment of neonatal respiratory distress syndrome.

This work was supported by research grants from Physicians' Services Incorporated, the Hospital for Sick Children Foundation, and the Children's Hospital of Eastern Ontario Research Institute.

1 Mannino FL, Merritt TA. The management of respiratory distress syndrome. In: Thibeault DW, Gregory GA, eds. distress syndrome. In: Thibeault DW, Gregory GA, eds. Neonatal pulmonary

2 Ballard PL. Beta-adrenergic agonists. Monogr Endocrinol 1986;28:236-77.

3 Roberts JM, Musci J. Alveolar $\beta$-adrenoreceptors: modulation and role in perinatal adaptation. In: Johnston BM, Gluckman PD, eds. Respiratory control and lung development in the fetus and newborn. Ithaca: Perinatology Press, 1986:135-60.

4 Wagner JE, Manning PJ. The biology of the guinea pig. New York: Academic Press, 1976:87-8.

5 Collins MH, Kleinerman J, Moessinger AC, Collins AH, James LS, Blanc WA. Morphometric analysis of the growth of the normal fetal guinea pig lung. Anat Rec growth of the no

6 Langston C, Kida K, Reed M, Thurlbeck WM. Human lung growth in late gestation and in the neonate. Am Rev Respir Dis 1984;129:607-13.

7 Pringle KC. Human fetal iung development and related animal models. Clin Obstet Gynecol 1986;29:502-13.

8 Lechner AJ, Banchero N. Advanced pulmonary development in newborn guinea pigs. Am f Anat 1982;163:23546.

9 Sosenko IRS, Frank L. Lung development in the fetal guinea pig: surfactant, morphology, and premature viability. Pediatr Res 1987;21:427-31.

10 Sosenko IRS, Frank L. Guinea pig lung development: antioxidant enzymes and premature survival in high $\mathrm{O}_{2}$. Am $\mathcal{\text { P Physiol } 1 9 8 7 ; 2 5 2 : \text { R693-8. }}$.

11 Government of Ontario: Animals for Research Act, Revised Statutes of Ontario 1980. Chapter 22, Regulations 16, 17, Statutes of Ontario 1980. Chapter 22, Regulations 16, 17,
18, 19. Revised Regulations of Ontario 1980, December 18,19 .

12 Draper RL. The prenatal growth of the guinea-pig. Anat Rec 1920;18:369-92.

13 Davis DJ, Dattel BJ, Ballard PL, Roberts JM. $\beta$-adrenergic receptors and cyclic adenosine monophosphate generation in human fetal lung. Pediatr Res 1987;21:142-7.

14 Bradford MM. A rapid and sensitive method for the quantitation of microgram quantities of protein utilizing the principle of protein-dye binding. Anal Biochem 1976;72:248-54.

15 Roberts JM. Techniques for the direct examination of adrenergic receptors in developmental studies. In: Nathanielsz PW, ed. Animal models in fetal medicine, Ithaca: Perinatology Press, 1986:187-68.

16 Snyder JM, Johnston JM, Mendelson CR. The effect of cortisol on rabbit fetal lung maturation in vitro. Dev Biol 1981;85:129-40.

17 Folch J, Lees M, Sloane Stanley GH. A simple method for 
the isolation and purification of total lipides from animal tissues. F Biol Chem 1956;226:497-509.

18 Touchstone JC, Chen JC, Beaver KM. Improved separation of phospholipids in thin layer chromatography. Lipids 1979;15:61-2.

19 Wilcox RE, Hightower WH, Smith RV. Post-hoc data analysis in biomedical research. Am Lab 1979;11:32-45.

20 Dobbs LG, Mason RJ. Pulmonary alveolar type II cells Dobbs LG, Mason RJ. Pulmonary alveolar type
isolated from rats. 7 Clin Invest 1979;63:378-87.

21 Brown LAS, Longmore WJ. Adrenergic and cholinergic Brown LAS, Longmore WJ. Adrenergic and cholinergic
regulation of lung surfactant secretion in the isolated perfused rat lung and in the alveolar type II cell in culture. F Biol Chem 1981;256:66-72.

22 Mettler NR, Gray ME, Schuffman S, LeQuire VS. $\beta$ adrenergic induced synthesis and secretion of phosphatidylcholine by isolated pulmonary alveolar type II cells. Lab Invest 1981;45:575-86.

23 Odom MJ, Snyder JM, Mendelson CR. Adenosine 3', $5^{\prime}$ monophosphate analogs and $\beta$-adrenergic agonists induce the synthesis of the major surt fetal lung in vitro. Endocrinology 1987;121:1155-63.

24 Fisher AB, Arad I, Dodia C, Chander A, Feinstein SI. cAMP increased synthesis of surfactant associated protein A by perfused rat lung. Am $f$ Physiol 1991;260:L226-33. 25 Falkay G, Nemeth G, Kovacs L. Binding properties of beta-adrenergic receptors in early human fetal lung. Biochem Biophys Res Commun 1986;135:816-22.
26 Whitsett JA, Manton MA, Darovec-Beckerman C, Adams $\mathrm{KG}$, Moore JJ. $\beta$-adenergic receptors in the developing rabbit lung. Am f Physiol 1981;240:E351-7.

27 Whitsett JA, Manton MA, Darovec-Beckerman C, Adams KG. $\beta$-adrenergic receptors and catecholamines sensitive to adenylate cyclase in the developing rat lung. Life Sci to adenylate cycl

28 Engel G. Subclasses of beta-adrenoreceptors - a quantitative estimation of beta ${ }_{1}$ and beta, adrenoceptors in guinea pig and human lung. Postgrad Med $\mathcal{f} 1981 ; 57$ (Suppl 1):77-83

29 Das SK, Sikpi MO, Skolnick P. Heterogeneity of $\beta$-adrenoreceptors in guinea pig alveolar type II cells. Biochem Biophys Res Commun 1987;142:898-903.

30 Gatto C, Johnson MG, Seybold V, Kulik TJ, Lock JE, Johnson DE. Distribution and quantitative developmental changes in guinea pig pulmonary $\beta$-receptors. $\mathcal{f}$ Appl Physiol: Respirat Environ Exercise Physiol 1984;57:1901-7.

31 McDonald JV Jr, Gonzales LW, Ballard PL, Pitha J, Roberts JM. Lung beta-adrenoreceptor blockade affects perinatal surfactant release but not lung water. $\mathcal{f} A \mathrm{ppl}$ perinatal surfactant release

32 Davis DJ, Jacobs M, Gonzales L, Ballard PL, Roberts JM. Beta-adrenergic receptors and cAMP response increase during explant culture of human fetal lung: partial inhibition by dexamethasone. Pediatr Res 1990;28:190-5. 